\title{
Maturation of seeds of Poincianella pluviosa (Caesalpinoideae) ${ }^{1}$
}

\author{
João Paulo Naldi Silva ${ }^{2 *}$, Danilo da Cruz Centeno ${ }^{3}$, \\ Rita de Cássia Leone Figueiredo-Ribeiro ${ }^{4}$, Claudio José Barbedo²
}

\begin{abstract}
The persistence of viable seeds in the soil is an important way to assure plant propagation, especially for species which produce seeds with short lifespan. Poincianella pluviosa is a tree species which seeds have short to medium storability at room temperature. The comprehension of the maturation process is crucial to understand its strategy for propagation and it could provide tools to improve seed viability in ex situ conditions. Flowers were tagged in two consecutive cycles of maturation and pods were periodically harvested until dispersion. Seeds were classified based on their morpho-physiological features, capability to germinate and develop seedlings. The complete maturation process was attained 315-330 days after anthesis, a period longer than reported for seed viability at room temperature. The maximum dry mass and seed vigor were reached at the end of maturation, although elevated seedling production was obtained before physiological maturity. We suggest that the precocious ability to produce seedlings in a long maturation could be a strategy to overcome environmental constraints, as the species is distributed in a wide range of phytogeographic domains in Brazil.
\end{abstract}

Index terms: ex situ conservation, physiological maturity, seed shedding, seed maturation, sibipiruna.

\section{Maturação de sementes de Poincianella pluviosa (Caesalpinoideae)}

\begin{abstract}
RESUMO - A manutenção de sementes viáveis no solo é uma forma importante para garantir a propagação, especialmente para espécies que produzem sementes de vida útil curta. Poincianella pluviosa é uma espécie arbórea cujas sementes apresentam curto a médio período de armazenamento em condições de laboratório. Assim, a compreensão do processo de maturação é fundamental para entender as estratégias de propagação da espécie, representando uma ferramenta para aprimorar a viabilidade das sementes em condições ex situ. As flores foram marcadas em dois ciclos de maturação consecutivos e os frutos foram colhidos até dispersão. As sementes foram classificadas de acordo com suas características morfofisiológicas e a capacidade de germinar e desenvolver plântulas. Observou-se que o processo completo de maturação (315-330 dias após antese) é maior do que o tempo descrito na literatura para manutenção da viabilidade destas sementes em temperatura ambiente. Valores máximos de massa seca e vigor foram alcançados no final da maturação, embora elevada produção de plântulas tenha sido obtida antes da maturidade fisiológica. Sugere-se que a capacidade precoce de produzir plântulas em um longo período de maturação poderia ser uma estratégia para superar limitações ambientais, já que a espécie está distribuída em diversos domínios fitogeográficos no Brasil.
\end{abstract}

Termos para indexação: conservação ex situ, dispersão de sementes, maturação de sementes, maturidade fisiológica, sibipiruna.

\section{Introduction}

Some seeds can maintain viability for thousands of years, representing an important feature for plant survival (Sallon et al., 2008). However, the longevity of seeds can be regulated by how advanced is the maturation process at the moment they are dispersed. An incomplete process can result in both poor seed germination and low persistence in the seed bank and produce

${ }^{1}$ Submitted on 03/06/2015. Accepted for publication on 05/11/2015. 2Instituto de Botânica, Núcleo de Pesquisa em Sementes, Caixa Postal, 68041, 04301012 - São Paulo, SP, Brasil.

${ }^{3}$ Universidade Federal do ABC, Centro de Ciências Naturais e Humanas, 09606-070 - São Bernardo do Campo, SP, Brasil. seed lots with low vigor (Kermode, 1990; Barbedo et al., 2002). On the other hand, late harvesting can accelerate seed deterioration due to adverse environmental conditions, which are frequently unsuitable for seed storage (Butler et al., 2009). Therefore, characterization of the maturation cycle is important to infer how long the soil seed bank will be available for propagation, as well as for defining the harvest timing to maintain longer seed viability during storage.

${ }^{4}$ Instituto de Botânica, Centro de Pesquisa em Ecologia e Fisiologia Caixa-Postal, 68041, 04301902 - São Paulo, SP, Brasil.

*Corresponding author <silvajpn7@gmail.com> 
Seed development starts with the fertilization of the ovule followed by a period of extensive cell division and differentiation. After that, dry matter is transferred from the mother plant to the seed which has its water content progressively reduced (Bewley et al., 2013) until abscission indicating, for most species, the end of reserve accumulation and the achievement of mass maturity (Ellis and Pieta Filho, 1992).

Poincianella pluviosa (DC.) L.P.Queiroz (= Caesalpinia pluviosa DC.; = Caesalpinia peltophoroides Benth.) is a member of Leguminosae, one of the most numerous and important neo-tropical families. Its taxonomic classification was reviewed (Lewis, 1998; Queiroz, 2009) but is still under discussion (Souza et al., 2013). This species shows a wide distribution in Brazil, covering various phytogeographic domains (Amazon, Caatinga, Cerrado, Atlantic forest and Pantanal - Queiroz, 2009; Lewis, 2015). Except for an ontogenetic study (Souza et al., 2013), limited information about seeds of this species is available. They are neither photosensitive nor show physical dormancy (Ferraz-Grande and Takaki, 2006) and are viable at room temperature for 240 days (Figliolia et al., 2001; Pontes et al., 2006). These seeds accumulate predominantly lipids, approximately $50 \%$ of total weight (Corte et al., 2006).

In this study we characterized the physiological maturity of seeds of $P$. pluviosa and described morphological and physiological changes occurring during the whole maturation period aiming to understand this process and to contribute to the conservation strategies of an underexploited neo-tropical species.

\section{Material and Methods}

\section{Plant material}

Trees (ca. 35) planted in the Rubião $\mathrm{Jr}$ campus of the Universidade Estadual Paulista (UNESP) in Botucatu, SP, Brazil (22052'20'S 48'26'37'W) had inflorescences tagged at the beginning of their anthesis in two consecutive maturation periods: September/2009 to August/2010 (referred as 2009/10) and September/2010 to July/2011 (referred as 2010/11). Pods were harvested directly from the branches at $80,161,203,217,245,259,285,301$ and 315 days after anthesis (DAA) in 2009/10 and at 97, 174, 202, 216, 230, $245,258,286,301,317$ and 323 DAA, in 2010/11. Fruits and seeds obtained for each stage were characterized as described below. The estimated time to reach each stage was calculated and considered as the age of fruits/seeds. Additionally, seeds were obtained directly from the ground, not exceeding $48 \mathrm{~h}$ after shedding, which were named recently-dispersed seeds (RDS). A voucher specimen from this species is deposited in the SP Herbarium of the Universidade Estadual Paulista
(UNESP) in Botucatu, SP, Brazil, number BOTU 1745 (Col. Garde Filho, D. 05/10/1971).

\section{Fruit and seed analysis}

Fruits and seeds were manually removed from the pods and characterized biometrically (three replicates of five fruits or fifteen seeds) with respect to color, texture and size (length, width and thickness, in mm). The water content ( $g$ of water per g of dry weight, g. $\left.\mathrm{g}^{-1}\right)$ and dry mass (g. seed $\left.{ }^{-1}\right)$ were determined gravimetrically in an oven at $103{ }^{\circ} \mathrm{C} \pm 3{ }^{\circ} \mathrm{C}$ for $17 \mathrm{~h}$, according to ISTA (2015) with four replicates of five seeds. The water potential was measured with a Decagon WP4 potentiometer (Pullman, USA) based on the dew point temperature of the air after equilibrium with the sample, according to Bonjovani and Barbedo (2008). The assessment of the water potential was performed by sorption isotherms in solutions of polyethylene glycol (PEG 6000) at different osmotic potentials, based on Michel and Kaufmann (1973).

Germination tests were carried out in four replications of 15 seeds each, using two sheets for the base and one for the covering of Germitest paper previously moistened with tap water (ISTA, 2015). The rolls were maintained in a germination chamber $\left(25 \pm 1{ }^{\circ} \mathrm{C}\right)$ and were evaluated every 2 days until 40 days, registering the percentage of germinated seeds (protrusion of at least $5 \mathrm{~mm}$ of primary root), normal seedling development (seedlings with at least $3 \mathrm{~cm}$ and no visual malformations) and, at the end of the analysis the speed of germination-aid was calculated according to Maguire (1962).

\section{Meteorological data}

The harvest site is classified as a semideciduous forest and the climate is Cwa, i.e., humid temperate with dry winter and hot summer, according to Köppen classification, and it is located at $827 \mathrm{~m}$ above sea level (CEPAGRI, 2015). Values of minimum and maximum temperatures and rainfall from flowering to shedding for both periods were obtained in an automatic meteorological station located in the Rubião Jr campus in Botucatu (SP).

\section{Statistical analysis}

Data are means \pm standard deviation of four replicates of 20 seeds per treatment for the physical and physiological analyses. The experiments were carried out with a completely randomized design and data were statistically analyzed by ANOVA, using $t$-test at $5 \%$ probability for the comparison of the two maturation periods (Santana and Ranal, 2004).

\section{Results and Discussion}

The maturation process of seeds of $P$. pluviosa is characterized by 13 distinct stages distributed in a complete cycle of 330 DAA 
or 11 months (Figure 1). Long periods of seed maturation were also described for other species, as exampled by Cedrela fissilis (8-9 months), Coffea sp. (7-12 months), Hypodiscus aristatus (18 months), and some palms (from 180 to 400 days - Chapin, 1999; Corvello et al., 1999; Dussert et al., 2000; Newton et al., 2002; Eira et al., 2006; Pérez et al., 2012).

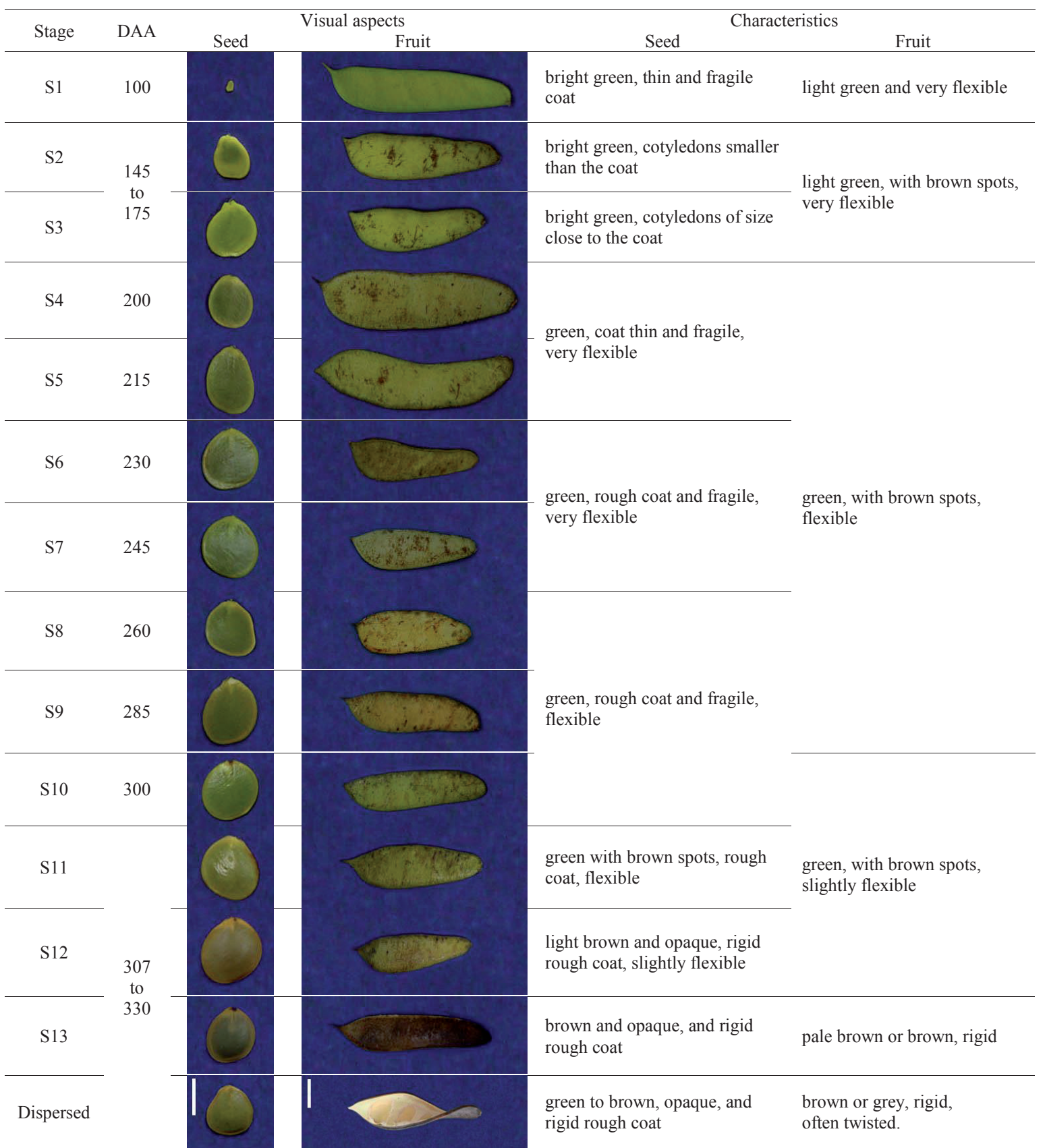

Figure 1. Morphological characteristics of P. pluviosa fruits and seeds in 13 stages of maturation. The pods were harvested directly from the branches of marked flowers and the estimated time to reach each stage was calculated after two periods of observation: Sep/09 to Aug/10 (2009/10) and Sep/10 to Jul/11 (2010/11). Bars: seeds= $1 \mathrm{~cm}$, fruits= $2 \mathrm{~cm}$.

Despite the long time needed to complete seed development and maturation, the major changes were observed just at the end of the process when the fruits become brown at the same time they become rigid (S13), and could indicate last stage before dehiscence. After seed dispersion, the fruits are usually twisted, dry and detached from the 
mother plant. The seed coat of P. pluviosa was green until 300 DAA, when turned completely to brown (Figure 1). It was possible to find some dispersed seeds with green color. For a practical purpose aiming to identify seed maturity, the color of the fruits could be grouped into five main stages ( $\mathrm{S} 1, \mathrm{~S} 2$ to S3, S4 to S9, S10 to S12 and S13), as shown in Figure 1.

The size of the seeds showed a different pattern of development when compared to fruit dimensions (Figure 2). Length, width and thickness of seeds reached maximum values at the end of maturation (Figures 2B, D, F), precisely at stage 12, and could indicate that the point of maximum seed dry matter accumulation is close to shedding. On the other hand, there was no significant variation in fruit size during almost all the maturation process (Figures 2A, C), except thickness, which slightly increased until 300 DAA (Figure $2 \mathrm{E}$ ), and could be related to seed dry matter accumulation (Figure 3B). The decrease in fruit thickness and in seed size at late maturation (Figures 2B, D, F) could be related to water loss (Figure 3A), corresponding to the natural desiccation at the end of seed maturation.
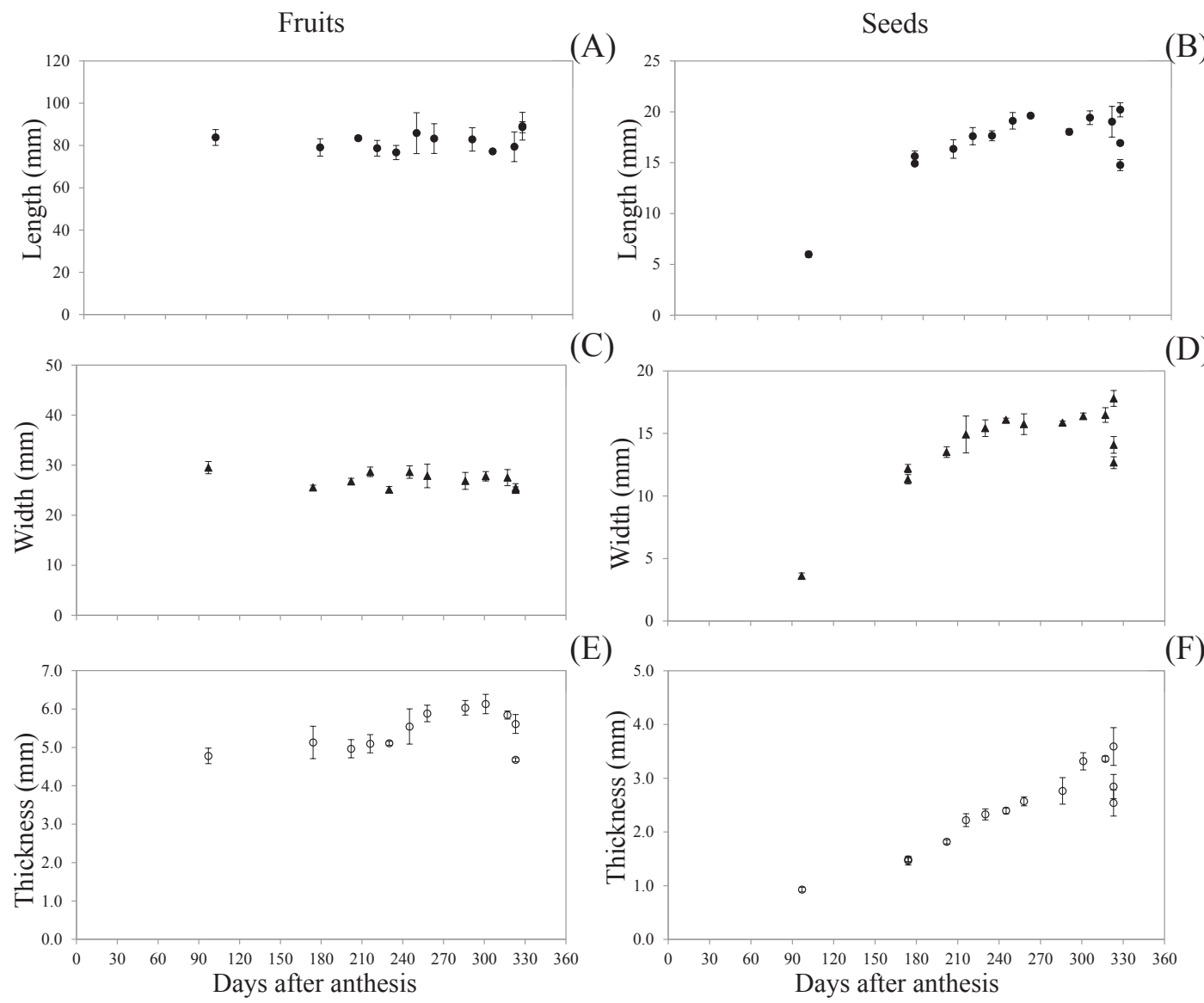

Figure 2. Length, width and thickness of P. pluviosa fruits (A, C and E) and seeds (B, D and F) collected from Sep/10 to Jul/11 $(2010 / 11)$ in different stages at Rubião Jr. campus, Botucatu (SP, Brazil). Data are mean \pm SD of three replicates of five fruits or fifteen seeds.

Indeed, water content gradually decreased from the beginning

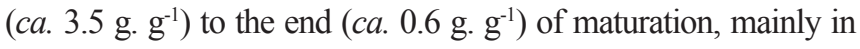
the last stages (Figure 3A). It is interesting to note that, despite the reduced water content, the water potential remained unchanged during most part of the maturation process (Figure 3A). In recently dispersed seeds (RDS), the water content and water potential reached the lowest values obtained in this study ( 0.11 and 0.09 g. $\mathrm{g}^{-1},-64.5$ and $-73.4 \mathrm{MPa}$, respectively, Figure 3A). Dry matter accumulation, similar in both analyzed periods, increased gradually until the last month of analysis. However, seeds of 2010/11 had higher dry matter than 2009/10, mainly at stage

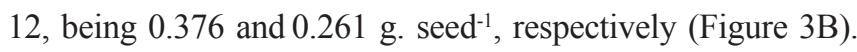
These could be associated with differences in environmental conditions, mainly rainfall and temperature as also observed for other species (Daws et al., 2004; Martins et al., 2009). In Eugenia pyriformis, for example, seed dry matter accumulation 
was influenced by temperature variations between two consecutive years (Lamarca et al., 2013). In P. pluviosa, besides temperature, rainfall distribution also seemed to affect dry mass accumulation once the highest range of temperature and more defined rainfall frequency were registered in 2010/11 (Figure 4B). However, the evaluation of temperature and rainfall variations in $P$. pluviosa seed development needs more investigation with an experimental approach.
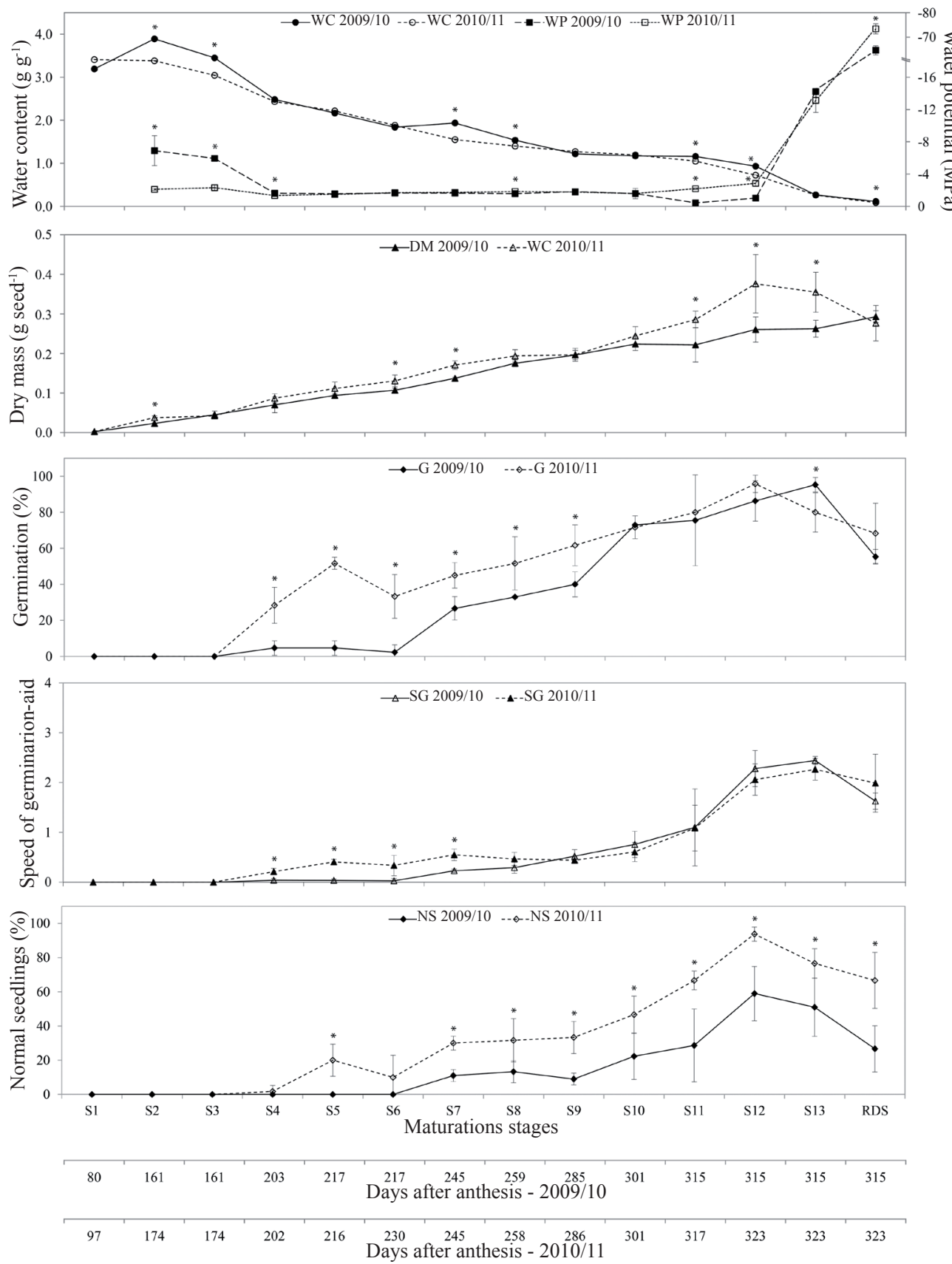

Figure 3. Physical and physiological characterization (mean $\pm \mathrm{SD}$ ) of $P$. pluviosa seeds at each stage of maturation in two consecutive cycles: Sep/09 to Aug/10 (2009/10) and Sep/10 to Jul/11 (2010/11). Water content (WC - g. $\left.\mathrm{g}^{-1}\right)$ and water potential (WP - MPa) - (A); Dry matter (DM - g. $\left.\operatorname{seed}^{-1}\right)$ - (B); Germination (G - \%) - (C); Speed of germination-aid (SG) - (D); Normal seedlings (NS - \%) - (E). Asterisks indicate significant difference among the maturation periods ( $t$ test, $P<0.05, n=4)$. 
The higher percentage of $P$. pluviosa seeds capable to germinate in the second period of analysis (2010/11) seems to be related with optimal environmental conditions during seed development (Figure 3C), when higher temperature ranges were registered, especially after 200 DAA (Figure 4). Increase of air temperature during seed development increased germinability of various species (Fenner, 1991; Martins et al., 2009), while under lower temperature (Figure 4A) less dry matter is accumulated and seeds have lower capacity to produce normal seedlings, as also reported by Kermode (1990) for a number of species. However, seeds obtained at 300 DAA in both cycles had the same germination percentage (around 70\%) and reached maximal values $(100 \%)$ at stages 12 and 13 (Figures 3C, D). The main difference between the two maturation cycles regards to seed capability to produce normal seedlings, which was higher in 2010/11 (Figure 3E).

Seeds of $P$. pluviosa are dispersed in the driest period of the year (July to August, Figure 4) in the southeast region of Brazil, which is consistent with seed tolerance to water stress, as suggested by Daws et al. (2004); Dussert et al. (2000) and Pritchard et al. (2004) for other species. Moreover, minimal temperatures at the time of seed dispersal in the regions of natural occurrence of this species are typically around $10{ }^{\circ} \mathrm{C}$ (INMET, 2015). Despite their short storability at room temperature ( 8 months - Figliolia et al., 2001), seeds of $P$. pluviosa could be viable in natural environment until the next rainy period (December to January, Figure 4).

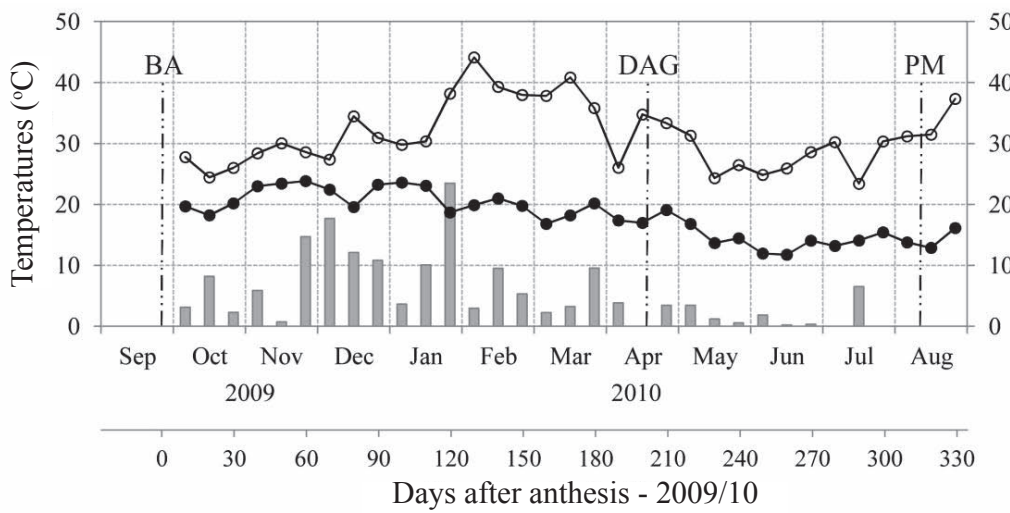

(A)

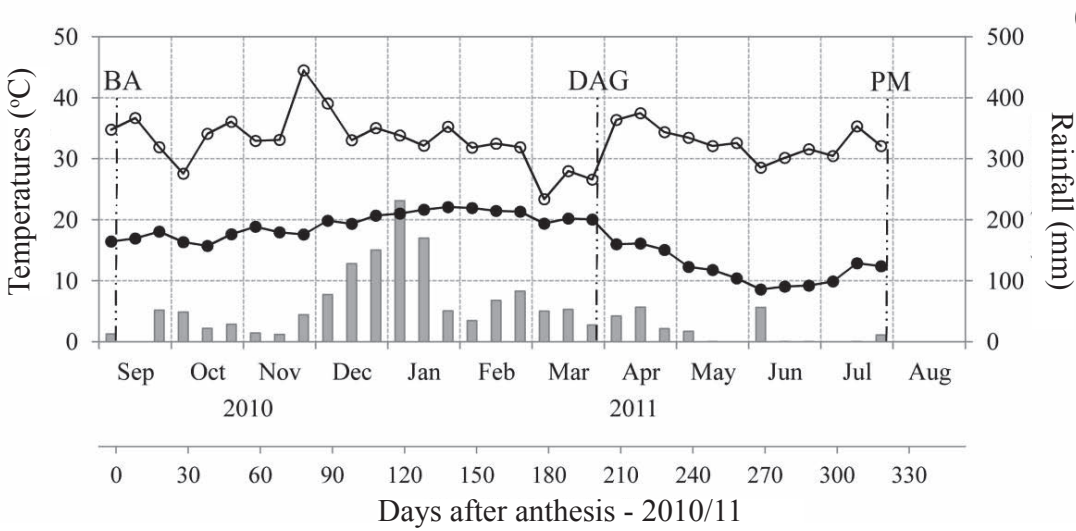

(B)

Figure 4. Meteorological data from the study site at Botucatu (SP, Brazil), in two complete periods of $P$. pluviosa seeds maturation: Sep/09 to Aug/10 (2009/10) - (A); Sep/10 to Jul/11 (2010/11) - (B). Maximum (O) and minimum (•) temperatures and rainfall (columns). The beginning of the anthesis (BA), development of ability to germinate (DAG), and physiological maturity point (PM) are indicated to each analyzed period.

Poincianella pluviosa RDS, as shown in this study, are not the most suitable material for storage and seedling production as those from stage 13, since RDS had lower rates of germination and seedling development (Figures 3C, E). Such seeds do not present physical dormancy (Ferraz-Grande and Takaki, 2006) as mentioned before and deteriorate a week after the germination tests, indicating biological degradation after shedding. Additionally, the RDS lot contained green seeds possibly due to asynchronous maturation of $P$. pluviosa seeds, similarly to what was reported for the flowering and fruiting processes of this species (Lewis and Gibbs, 1999). Therefore, some immature seeds can be dispersed with the mature ones, 
resulting in a heterogeneous lot with lower germination and seedling production. The implication of dispersal of immature seeds in neo-tropical forests has been discussed, emphasizing that the degree of immaturity in which seeds are detached from the mother plant is crucial for desiccation tolerance and seed longevity in such environments (Barbedo et al., 2013).

Seeds of $P$. pluviosa contained the highest dry mass (i.e., physiological maturity, Bewley et al., 2013) between 315-323 DAA (stage 12), immediately before the natural desiccation. Some authors consider that the increase in seed quality, including seed longevity, can occur between periods of maximum accumulation of dry matter and seed dispersion (Hay and Probert ,1995; Probert et al., 2007). According to this concept, seeds of P. pluviosa should be harvested at stage 13 , when natural desiccation already occurred and their water content was close to $0.26 \mathrm{~g}^{-1} \mathrm{~g}^{-1}$ (Figure 3A).

While tolerant to desiccation, seeds of P. pluviosa do not exhibit some other characteristics typically found in classic models of tolerant seeds. They accumulate cyclitols instead of raffinose family oligosaccharides (Silva, JPN unpublished data), both related to membrane stabilization in the dry state (Obendorf, 1997). On the other hand, the maturation process of P. pluviosa is so extensive that exceeds the reported viability of such seeds during storage at room temperature (Figliolia et al., 2001).

Altogether, our findings highlight that $P$. pluviosa seeds have the ability to develop normal seedlings very early during the long maturation cycle. This behavior could propitiate maintaining seeds able to produce new plantlets even during the maturation process, possibly allowing seedling establishment in different periods and climatic conditions. Future work will enable the determination of the viability of immature seeds and seedlings in environmental conditions and under stressed treatments, such as drought. The information provided here contributes to a better understanding of seed behavior allowing the possibility to obtain high quality seeds of this important neotropical species.

\section{Conclusions}

The complete maturation process of P. pluviosa seeds was attained 315-330 days after anthesis (DAA). The maximum dry mass and seed vigor were reached close to 320 DAA, although high production of seedlings was obtained before physiological maturity.

\section{Acknowledgements}

The authors thank the Administration of the Instituto de Biociências, Rubião Jr Campus, for the permission to harvest seeds and Juliana Iassia Gimenez for helping to collect fruits. This research work is part of JPN Silva PhD thesis supported by a fellowship from Coordenação de Aperfeiçoamento de Pessoal de Nível Superior - CAPES. CJ Barbedo is a research fellow of Conselho Nacional de Desenvolvimento Científico e Tecnológico - CNPq. This research work was financially supported by CNPq n ${ }^{\circ} 478298 / 2011$.

\section{References}

BARBEDO, C.J.; BILIA, D.A.C.; FIGUEIREDO-RIBEIRO, R.C.L. Tolerância à dessecação e armazenamento de sementes de Caesalpinia echinata L. (pau-brasil). Brazilian Journal of Botany, v.25, p.431-439, 2002. http://www.scielo.br/pdf/rbb/v25n4/a07v25n4.pdf

BARBEDO, C.J.; CENTENO, D.C.; FIGUEIREDO-RIBEIRO, R.C.L. Do recalcitrantseeds really exist? Hoehnea, v.40,n.4,p.583-595, 2013. http://www. scielo.br/scielo.php?script=sci_arttext\&pid=S2236-89062013000400001

BEWLEY, J.D.; BRADFORD, K.J.; HILHORST, H.W.M.; NONOGAKI, H. Seeds: Physiology of Development, Germination and Dormancy. New York: Springer, 2013. 392p. http://www.springer.com/ new $+\% 26+$ forthcoming + titles $+\% 28$ default $\% 29 /$ book/978-1-4614-4692-7

BONJOVANI, M.R.; BARBEDO, C.J. Sementes recalcitrantes: intolerantes a baixas temperaturas? Embriões recalcitrantes de Inga vera Willd. subsp. affinis (DC.) T.D.Penn. toleram temperatura sub-zero. Brazilian Journal of Botany, v.32, p.345-356, 2008. http://dx.doi.org/10.1590/S0100-84042008000200017

BUTLER, L.H.; HAY, F.R.; ELLIS, R.H.; SMITH, R.D. Post-abscission, predispersal seeds of Digitalis purpurea remain in a developmental state that is not terminated by desiccation ex planta. Annals of Botany, v.103, p.785-794, 2009. http://aob.oxfordjournals.org/content/early/2009/01/09/aob.men254.full

CEPAGRI. Centro de Pesquisas Meteorológicas e Climáticas Aplicadas à Agricultura. Clima dos Municípios Paulistas, Campinas. http://www.cpa.unicamp. br/outras-informacoes/clima_muni_463.html. Accessed on: Feb 20 2015.

CHAPIN, M.H. Flowering and fruiting phenology in certain palms. Palms, v.43, p.161-165, 1999. http://www.cabdirect.org/abstracts/20000310066.html

CORTE, V.B.;BORGES,E.E.L.; PONTES, C.A.;LEITES, I.T.A.;VENTRELLA, M.C.; MATHIAS, A.A. Mobilização de reservas durante a germinação das sementes e crescimento das plântulas de Caesalpinia peltophoroides Benth. (Leguminosa e- Caesalpinoideae). Revista Árvore, v.30, p.941-949, 2006. http:// www.scielo.br/scielo.php?pid=s0100-67622006000600009\&script=sci_arttext

CORVELLO, W.B.V.; VILLELA, F.A.; NEDEL, J.L.; PESKE, S.T. Maturação fisiológica de sementes de cedro (Cedrela fissilis Vell.). Revista Brasileira de Sementes, v.21, p.23-27, 1999. http://www.abrates.org.br/ revista/artigos/1999/v21n2/artigo04.pdf

DAWS, M.I.; LYDALL, E.; CHMIELARZ, P.; LEPRINCE, O.; MATTHEWS, S.; THANOS, C.A.; PRITCHARD, H.W. Developmental heat sum influences recalcitrant seed traits in Aesculus hippocastanum across Europe. New Phytologist, v.162, p.157-166, 2004. http://onlinelibrary.wiley. com/doi/10.1111/j.1469-8137.2004.01012.x/full 
DUSSERT, S.; CHABRILLANGE, N.; ENGELMANN, F.; ANTHONY, F.; LOUARN, J.; HAMON, S. Relationship between seed desiccation sensitivity, seed water content at maturity and climatic characteristics of native environments of nine Coffea L. species. Seed Science Research, v.10, p.293-300, 2000. http:// journals.cambridge.org/action/displayAbstract? fromPage $=$ online $\&$ aid $=695464$

EIRA, M.T.S.; SILVA, E.A.A.; CASTRO, R.D.; DUSSERT, S.; WALTERS, C.; BEWLEY, D.; HILHORST, H.W.M. Coffee seed physiology. Brazilian Journal of Plant Physiology, v.18, p.149-163, 2006. http://dx.doi.org/10.1590/ S1677-04202006000100011

ELLIS, R.H.; PIETA FILHO, C. The development of seed quality in spring and winter cultivars of barley and wheat. Seed Science Research, v.2, p.9-15, 1992. http:// journals.cambridge.org/action/displayAbstract?fromPage $=$ online\&aid $=1351384$

FENNER, M. The effects of the parent environment on seed germinability. Seed Science Research, v.1, p.75-84, 1991. http://dx.doi.org/10.1017/ S0960258500000696

FERRAZ-GRANDE, F.G.A.; TAKAKI, M. Efeitos da luz, temperatura e estresse de água na germinação de sementes de Caesalpinia peltophoroides Benth. (Caesalpinoideae). Bragantia, v.65, p.37-42, 2006. http://www.scielo. br/scielo.php?script=sci arttext\&pid=S0006-87052006000100006

FIGLIOLIA, M.B.; SILVA, A.; AGUIAR, I.B.; PERECIN, D. Efeito do acondicionamento e do ambiente de armazenamento na conservação de sementes de sibipiruna. Revista Brasileira de Horticultura Ornamental, v.7, p.57-62, 2001. http://rbho.emnuvens.com.br/rbho/article/view/78

HAY, F.R.; PROBERT, R.J. Seed maturity and the effects of different drying conditions on desiccation tolerance and seed longevity in foxglove (Digitalis purpurea L.). Annals of Botany, v.76, p.639-647, 1995. http://aob. oxfordjournals.org/content/76/6/639

ISTA. International Seed Testing Association. International rules for seed testing. Seed Science and Technology, v.13, p.356-513, 2015. https://www. seedtest.org/en/international-rules-_content--1--1083.html

INMET. Instituto Nacional de Meteorologia. Ministério da Agricultura, Pecuária e Abastecimento, Brasília. http://www.inmet.gov.br/portal/index. php?r=bdmep/bdmep. Acessed on: Feb $20^{\text {th }}, 2015$.

KERMODE, A.R. Regulatory mechanisms involved in the transition from seed development to germination. Critical Reviews in Plant Science, v.9, p.155-195, 1990. http://www.tandfonline.com/doi/abs/10.1080/07352689009382286

LAMARCA, E.V.; PRATAVIERA, J.S.; BORGES, I.F.; DELGADO, L.F.; TEIXEIRA, C.C.; CAMARGO, M.B.P.; FARIA, J.M.R.; BARBEDO, C.J. Maturation of Eugenia pyriformis seeds under different hydric and thermal conditions. Anais da Academia Brasileira de Ciências, v.85, p.223-233, 2013. http://dx.doi.org/10.1590/S0001-37652013005000006

LEWIS, G.P. Caesalpinia, a revision of the Poincianella-Erythrostemon group. Kew: Royal Botanic Gardens, 1998. 233p.

LEWIS, G.P. Poincianella in Lista de Espécies da Flora do Brasil. Jardim Botânico do Rio de Janeiro. http://floradobrasil.jbrj.gov.br/jabot/floradobrasil/ FB109778. Acessed on: Feb 20 2015.

LEWIS, G.P.; GIBBS, P. Reproductive biology of Caesalpinia calycina and C. pluviosa (Leguminosae) of the caatinga of north-eastern Brazil. Plant Systematics and Evolution, v.217, p.43-53, 1999. http://link.springer.com/ article/10.1007\%2FBF00984921
MAGUIRE, J.D. Speed of germination-aid in selection and evaluation for seedling emergence vigor. Crop Science, v.2, p.176-177, 1962. https://www. crops.org/publications/cs/abstracts/2/2/CS0020020176

MARTINS, C.C.; BOVI, M.L.A.; NAKAGAWA, J.; MACHADO, C.G. Secagem e armazenamento de sementes de juçara. Revista Árvore, v.33, p.635-642, 2009. http://www.scielo.br/scielo.php?script=sci arttext\&pid=S0100-67622009000400006

MICHEL, B.E.; KAUFMANN, M.R. The osmotic potential of polyethylene glycol 6000. Plant Physiology, v.51, p.914-916, 1973. http://www. plantphysiol.org/content/51/5/914.abstract

NEWTON, R.J.; BOND, W.J.; FARRANT, J.M. Seed development, morphology and quality in selected species of the nut-fruited Restionaceae. South African Journal of Botany, v.68, p.226-230, 2002. http://www.ajol. info/index.php/sajb/article/view/20524

OBENDORF,R.L.Oligosaccharides and galactosylcyclitolsinseeddesiccation tolerance. Seed Science Research, v.7, p.63-74, 1997. http://journals. cambridge.org/action/displayAbstract?fromPage $=$ online\&aid $=1293144$

PÉREZ, H.E.; HILL, L.M.; WALTERS, C. An analysis of embryo development in palm: interactions between dry matter accumulation and water relations in Pritchardia remota (Arecaceae). Seed Science Research, v.22, p.97-111, 2012. http://dx.doi.org/10.1017/S0960258511000523

PONTES, C.A.; CORTE, V.B.; BORGES, E.E.L.; SILVA, A.G.; BORGES, R.C.G. Influência da temperatura de armazenamento na qualidade das sementes de Caesalpinia peltophoroides Benth. (sibipiruna). Revista Árvore, v.30, p.43-48, 2006. http://www.scielo.br/scielo.php?script=sci arttext\&pid=S0100-67622006000100006

PRITCHARD, H.W.; DAWS, M.I.; FLETCHER, B.J.; GAMÉNÉ, C.S.; MSANGA, H.P.; OMONDI, W. Ecological correlates of seed desiccation tolerance in tropical African dryland trees. American Journal of Botany, v.91, p.863-870, 2004. http://www.ncbi.nlm.nih.gov/pubmed/21653442

PROBERT, R.J.; ADAMS, J.; CONEYBEER, J.; CRAWFORD, A.; HAY, F. Seed quality for conservation is critically affected by pre-storage factors. Australian Journal of Botany, v.55, p.326-335, 2007. http://dx.doi org/10.1071/BT06046

QUEIROZ, L.P. Leguminosas da Caatinga. Feira de Santana. Universidade Estadual de Feira de Santana, 2009. 914p. http://www.cabdirect.org/ abstracts/20113044322.html

SALLON, S.; SOLOWEY, E.; COHEN, Y.; KORCHINSKY, R.; EGLI, M.; WOODHATCH, I.; SIMCHONI, O.; KISLEV, M. Germination, genetics, and growth of an ancient date seed. Science, v.320, p.1464, 2008. http://www. sciencemag.org/content $/ 320 / 5882 / 1464$.short

SANTANA, D.G.; RANAL, M.A. Análise da germinação: um enfoque estatístico. 1. ed. Brasília. Universidade de Brasília, 2004. 248p. http://www. editora.unb.br/lstDetalhaProduto.aspx?pid=26

SOUZA, C.D.; MARINHO, C.R.; TEIXEIRA, S.P. Ontogeny resolves gland classification in two Caesalpinoid legumes. Trees, v.27, p.801-813, 2013. http://link.springer.com/article/10.1007\%2Fs00468-012-0835-z 